University of Nebraska - Lincoln

DigitalCommons@University of Nebraska - Lincoln

Agronomy \& Horticulture -- Faculty Publications

Agronomy and Horticulture Department

2017

\title{
Lettuce Learn: Student Reflections on Building and Sustaining a Community Donation Garden
}

\author{
Hannah Dankbar \\ Columbia River Estuary Study Taskforce, hdankbar@iastate.edu \\ Emily K. Zimmerman \\ lowa State University \\ Carrie Chennault \\ lowa State University \\ Andrea D. Basche \\ University of Nebraska-Lincoln, abasche2@unl.edu \\ Jacqueline Ann Nester \\ Monroe County, Indiana
}

See next page for additional authors

Follow this and additional works at: https://digitalcommons.unl.edu/agronomyfacpub

Part of the Agricultural Science Commons, Agriculture Commons, Agronomy and Crop Sciences Commons, Botany Commons, Horticulture Commons, Other Plant Sciences Commons, and the Plant Biology Commons

Dankbar, Hannah; Zimmerman, Emily K.; Chennault, Carrie; Basche, Andrea D.; Nester, Jacqueline Ann; Pierre, Maritza; and Roesch-McNally, Gabrielle, "Lettuce Learn: Student Reflections on Building and Sustaining a Community Donation Garden" (2017). Agronomy \& Horticulture -- Faculty Publications. 1126. https://digitalcommons.unl.edu/agronomyfacpub/1126

This Article is brought to you for free and open access by the Agronomy and Horticulture Department at DigitalCommons@University of Nebraska - Lincoln. It has been accepted for inclusion in Agronomy \& Horticulture -Faculty Publications by an authorized administrator of DigitalCommons@University of Nebraska - Lincoln. 


\section{Authors}

Hannah Dankbar, Emily K. Zimmerman, Carrie Chennault, Andrea D. Basche, Jacqueline Ann Nester, Maritza Pierre, and Gabrielle Roesch-McNally 


\section{JOURNAL OF CRITICAL THOUGHT AND PRAXIS}

IOWA STATE UNIVERSITY DIGITAL PRESS \& SCHOOL OF EDUCATION

Volume 6

Issue 3 Everyday Practices of Social Justice

Article 5

\section{Lettuce Learn: Student Reflections on Building and Sustaining a Community Donation Garden}

Hannah Dankbar, Emily K. Zimmerman, Carrie Chennault, Andrea Basche, Jacqueline Ann Nester, Maritza Pierre, \& Gabrielle Roesch-McNally

Follow this and additional works at: $\underline{\text { http://lib.dr.iastate.edu/jctp/vol6/iss3/ }}$

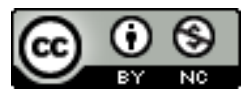

This article is distributed under a Creative Commons Attribution-NonCommercial 4.0 International License (CCBY-NC). Users may reproduce, disseminate, display, or adapt this article for non-commercial purposes, provided the author is properly cited. See https:/creativecommons.org/licenses/by-nc/4.0/.

The Journal of Critical Thought and Praxis is published by the Iowa State University School of Education and Iowa State University Digital Press. View the journal at http://lib.dr.iastate.edu/jctp/. 


\title{
Lettuce Learn:
}

\section{Student Reflections on Building and Sustaining a Community Donation Garden}

\author{
Hannah Dankbar* \\ Columbia River Estuary Study Taskforce \\ Andrea Basche \\ Union for Concerned Scientists \\ Emily K. Zimmerman \\ Carrie Chennault \\ Maritza Pierre \\ Jackie Nester \\ Iowa State University \\ Monroe County, Indiana \\ Gabrielle Roesch-McNally \\ Northwest Climate Hub
}

\begin{abstract}
This article emerged from conversations that we and fellow graduate students have had in building a community donation garden. We created the garden with a vision of enacting food justice in our community, but over the past four years we have experienced complexities with our vision. In this article, we share the complexities with which we have wrestled, how we have encouraged thoughtful dialogue among fellow scholars about these shortcomings and the intricate workings of the agrifood system, and the lessons we have learned through these experiences as early-career scholar-activists. This article represents our collective and individual voices as graduate student garden leaders reflecting on: (a) the ways in which we strived to integrate social justice into our local emergency food system; (b) the paradox of industrial commodity-oriented production agriculture designed to "feed the world," which neglects the production of healthy food that is locally produced and locally accessible; and (c) the holistic learning approach of combining academic studies with praxis. As students cycle through the graduate program, the garden and partnerships continue, and students take the lessons that they learn through this engagement into their careers and other activities.
\end{abstract}

Keywords: Food Justice | Emergency Food | Community Garden | Scholar Activist

Paradoxes of food and hunger are not new in the United States and, undoubtedly, the emergency food system is a key component of alleviating hunger. Seen as the dawn of public assistance programs, such as the food stamp program, the Great Depression era introduced the political notion that hunger relief in the form of an emergency food system could provide financial support for the economy (Nestle, 2014). Despite 80 years of public policies designed to reduce chronic hunger, the emergency food system remains incapable of meeting the basic nutritional needs of the one in eight (Feeding America, 2014), lowincome, food-insecure Americans who repeatedly face the prospect of turning to an

\footnotetext{
${ }^{*}$ Correspondence can be directed to Hannah Dankbar at hdankbar@gmail.com
} 
emergency food system not designed to be a regular, recurring source of food for individuals and families in need (Poppendieck, 2014, p. 260).

Public and non-profit partnerships such as food pantries, food banks, and religious organizations have evolved to provide important stopgap resources to meet immediate hunger needs. Nonetheless, these same emergency food resources often reinforce the very patterns that facilitate chronic food insecurity. To encourage charitable donations from agrifood businesses to food pantries and food banks within the emergency food system, federal laws - and many state laws - offer tax incentives for food donations. These donors may provide food products that would otherwise be wasted; as such, they are able to simultaneously incur tax deductions for their donations and avoid expensive tipping fees, while continuing to underpay and under-insure their employees (Goetz \& Swaminathan, 2006). Paradoxically, some of the large agribusiness firms producing and/or retailing the high-volume, cheap food that lines the shelves of food banks and pantries simultaneously underpay and underinsure employees who must also turn to emergency food resources. Acknowledging the need to encourage food donations on the one hand, we also saw how cost-savings and improved bottom lines feed into the vicious cycles of hunger in our country.

In this article, current and past graduate students reflect on their experiences of engaging with our local emergency food system by creating a donation garden and the value and importance that each of us has found in envisioning a just food system. We hope to show that through our experiences we have learned that local emergency food organizations can provide a starting point for food justice work through the disconnect that comes apparent through praxis. Quotes from each student are used to share individual reflections while contributing to the voice of the group. Collaboratively, we reflect on: (a) the ways in which we strived to integrate social justice into our local emergency food system; (b) the paradox of industrial commodity-oriented production agriculture designed to "feed the world," which neglects the production of healthy food that is locally produced and locally accessible; and (c) the holistic learning approach of combining academic studies with praxis.

This article is written with a multivocal, feminist-praxis framework; this means multiple, situated knowledges that are diverse, fluid, partial, and sometimes contradictory are presented together, allowing the authors to present their individual reflections while collaborating on a project (Haraway, 1988). The appendix contains full reflections from each author. ${ }^{1}$

\section{Our Praxis}

As scholar-activists, we have volunteered and done research within food pantries embedded in the emergency food system in our community. As Hale (2008) described, "activist scholars work in dialogue, collaboration, alliance with people who are struggling to better their lives” (p. 4) and work to build alliances to improve community well-being rather than focusing merely on scholarship that is primarily valued in academic institutions. Our academic studies combined with our volunteer efforts within emergency food pantries allowed us to experience the gap between our existing food system and ideals of building

\footnotetext{
${ }^{1}$ The appendix can be accessed on the Journal of Critical Thought and Praxis website for this article.
} 
greater food justice within our community. Food justice incorporates social justice ideals by striving for systemic changes that reduce inequalities, increase empowerment, and increase economic and labor systems within historically marginalized groups (Hayes and Carbone, 2015). These strategies are "integrated with practical efforts to establish fair, equitable access to fresh, healthy, affordable, culturally appropriate food in vulnerable neighborhoods, especially low-income neighborhoods and communities of color, with ownership and governance of the means of production and exchange accessible to the people who eat this healthy food" (Bradley and Herrera, 2016). Using a food justice lens, we reflected upon the current barriers preventing people in our own communities from accessing fresh, healthy foods.

This paper demonstrates how our experiences in the garden have allowed us to better understand the complexities we have wrestled with and how we have encouraged thoughtful dialogue among fellow scholars.

Jackie: Throughout our efforts to bring fresh food to the meals, our group often reflected on the root causes for why organizations like Food at First must exist. In addition, there were many opportunities where we could reflect on our own privilege and assumptions, such as our goals early-on to involve patrons in gardening without recognizing barriers to participation, such as: physical ability, interest, or time.

Each of us valued our volunteer efforts and saw them as a worthy way to spend our free time outside of academic work. This work brought us joy and frustration, particularly as it enhanced our "real-world" education that forced us to examine, the contradictions within our food system. We hope that this article contributes to the literature on food justice by providing a basis for which conflicting ideas within emergency food system work can lead to place-based conversations and idea sharing, as well as a starting point providing inspiration for community garden practitioners to reflect on the challenges and opportunities associated with their work.

\section{Partnership in Praxis}

Our volunteer efforts and the reflections throughout this article centered on a partnership developed between students in the Graduate Program in Sustainable Agriculture (GPSA) at Iowa State University, Food at First, and Trinity Christian Reform Church where the community garden is located. We recognized that without these partnerships the garden would not have been possible.

The GPSA is a unique, transdisciplinary graduate program that allows students to pursue a curriculum that addresses the biophysical, social and economic dimensions of the agrifood system. This was the first graduate program in Sustainable Agriculture to offer both an M.S. and Ph.D. Over the last 16 years, the GPSA has included students and faculty from over 20 departments in six of Iowa State's academic colleges. As co-authors on this paper, we represented five different departments, each with its own curriculum, process, and scholarship. The authors of this article studied: Agronomy (Andrea), Sociology (Gabrielle), Natural Resources Ecology and Management (Emily), Agricultural Education and Studies (Carrie), and Community and Regional Planning (Hannah, Jackie, and Maritza). This rich diversity of students is coupled with the purposeful recruitment of 
students who engage with food, environmental and agricultural organizations and programs in our broader communities.

In 2013, students in GPSA joined a partnership with Food at First and Trinity Christian Reformed Church after becoming aware that there was an abandoned garden space that could be harnessed to benefit the community. Food at First currently operates three perishable food distributions each week at two different locations along with a free meal program every day. The organization is a non-profit based in Ames, Iowa and began in 2004 as a way to distribute food to those in need. Food at First has a single part-time employee, but otherwise relies solely on thousands of volunteer hours per year. Volunteers gather unwanted food from local restaurants (e.g., Panera Bread Co., Iowa State University Dining, etc.) and retail locations (e.g., Walmart, Hy-Vee, Aldi, etc.), prepare food for the meal each day, and grow food that can be used in meals or taken home.

The partnership between GPSA, Food at First, and Trinity Christian Reformed Church led to students partnering to cook one meal a month at Food at First and to start a garden located on the lawn of Trinity Christian Reformed Church to (a) provide access and availability of fresh produce to clients of Food at First meals and pantry; and (b) engage the broader community in our local emergency food system. We were motivated to adopt the abandoned garden after being engaged with this organization by cooking a community meal each month and discovering that the meal program and food distribution program lacked sufficient amounts of fresh and local fruits and vegetables. Food at First and Trinity Christian Reformed Church were both aware of this problem and were interested in finding a community based solution. Without the interest and support from these organizations, the garden would not exist. Further motivated by an interest in the relationship between activism and scholarship and concern regarding the neoliberal, emergency food system, we have spent the past four years grappling with the complexities of local food systems and community development, and the emergency food system - following the life-cycle of food from the way it is produced and harvested (e.g. workers' rights of fair wages, benefits, etc.) and its availability, accessibility and affordability to all consumers.

\section{Integrating Social Justice into the Emergency Food System}

Our relationship with Food at First has been shaped by an uncomfortable duality: the realization that we are embedded within an unjust emergency food system, serving the immediate needs of the chronically food insecure while at the same time working as scholar-activists to create a community space that embraces food justice, or the right of poor communities to access healthy food. These interrelated concerns for the emergency food system are situated in a scholar-activist and practitioner movement to advance social justice and raise awareness about a food system that is built on a neoliberal political economy, which rests on the belief that individual well-being is best realized when the free market operates without state intervention (Alkon, 2014). This political economy gave us pause to consider underlying economic structural issues such as inequitable resource ownership and distribution identified by the food sovereignty movement (Holt-Giménez \& Wang, 2011; Jarosz, 2014). 
Jackie: Efforts like gleaning and processing food for our monthly meals served as a reflection that our current food system does not prioritize healthy food as a right, but rather a privilege.

Andrea: Our work to grow fresh produce at the garden as well as additional harvesting and processing efforts from other local farms were very time intensive endeavors. They also did not scratch the surface of need, assuming 50-100 people attend a daily meal and we aimed to provide some amount of their daily-recommended servings of fruits or vegetables.

Gabrielle: Fundamentally...we need to transform our agricultural system into something that is more holistic, that, at its core, produces healthy food for communities, farmers and farmworkers not just industrial commodities that serve to distance each of us from the consequences of our food choices.

We may make do with the stopgap structure and function of the emergency food system, but it is not a viable path forward because it neglects issues underlying food injustice such as oppression and racism. In addition, the emergency food system reinforces a food system that is based solely on economics and production rather than people and the health of the environment.

In the midst of these complexities, we have thought deeply about what a food just society should and could look like and what that means for our praxis.

Carrie: Ultimately, my praxis supports a deep, abiding optimism that the cracks and slips are there, the interstitial spaces in which we already slowly have begun to chip away at the dominant material-discursive formations of power. While we may personally experience an uneasiness holding together the contradictions of our location between dominant and alternative discourses, rather than frame our work with emergency food systems as (aligned with the) politically neoliberal, I suggest along the lines of feminist scholars like Mohanty (1984) and Katz (1992) that the contradictions of inbetweenness open up a space for political acts of social justice. Working at a donation garden, then, becomes a form of praxis, a way to do community differently.

Though Food at First operates like the mainstream emergency food system, it illustrates a unique model. In contrast to publicly funded programs, Food at First does not ask for socioeconomic information or customer identification. Anyone from the community is welcome at the distributions and meals, and people are welcome to come as many times as they would like. The uniqueness of this organization was attractive to our group.

Jackie: Food at First was my introduction to how social justice and food systems are connected. One of the reasons I joined in the efforts of Food at First was because they placed a high priority on human dignity by not questioning patrons.

Hannah: One of the reasons that I became involved at Food at First is because I believe in community food systems where people are actively involved in ensuring their neighbors have access to socially acceptable and nutritious foods. 
In addition, Food at First is well known for providing more than just food. RoeschMcNally et al. (forthcoming, 2017) found that Food at First was incredibly effective at building community among those who participated in the meal and pantry programs. Another unique feature of Food at First is the board. Like many non-profit organizations, Food at First uses volunteer board members to lead organization decisions and actions. The unique feature of Food at First is that many of the board members also visit the food distributions and join daily meals themselves. The Food at First organization is run by the very people that it also seeks to serve.

Gabrielle: As a student participant, volunteer, and garden leader, I can attest to the fact that I felt greater belonging among the other volunteers, my student colleagues, and the broader Ames community that participated in Food at First meals, pantry distributions or garden efforts as a result of my engagement in the community garden and meal program.

As scholars interested in sustainable food systems, we found it vital to engage with our own local and emergency food systems. We were empowered to build a garden and glean from local farms with a vision of enacting food justice by providing high quality fresh produce to those that cannot afford or access it in our own community. We quickly learned that the visions of food justice that we encounter in our academic work are plagued with issues when enacted in praxis. We experientially understood that the garden is vital as an important learning environment to graduate students who continue to cycle through our program. As evidenced in our reflections, the garden is a place of community, a place of discovering our own biases, and a place of confronting the worldviews through which we view the agrifood system. In addition, we had to accept that our aspirations for the garden might not match with the reality of what the garden is, or how the broader community views it.

Carrie: I spend time reflecting on, fretting about, and then finding comfort and reassurance in our work at the garden. The fretting comes from a fear of falling short of our lofty aspirations of social justice...Can a group of relatively privileged, university-affiliated, busy graduate students who typically move away in a few years establish trust with community members who have serious reason to distrust us? I don't know. We will keep working on it. For now, I do find solace in Gibson-Graham, Cameron and Healy's (2013) refusal to overlook alternative economies that define and legitimize practices of sharing situated outside of the normal economic relations of the late capitalist and neoliberal order.

\section{Volunteer Management}

Our most consistent challenge in the garden was volunteer management and engagement. We became involved in the garden because of our strong desire to build socially just community food systems, and while our community supports and applauds our efforts, the support does not go as far as rolling up their sleeves to join us in the garden work. Our initial expectation that more volunteers would engage in our efforts to increase fresh fruits 
and vegetables for Food at First patrons later revealed our assumptions and privilege embedded in our efforts.

Gabrielle: I had hoped, perhaps naively, that more members of the FAF community, including those who are food insecure, would more actively participate in the activities in the garden, from planting, harvesting, or joining in on cooking/preserving efforts. We tried a lot of strategies for bringing people into the garden but due to many factors, including my own naiveté, assuming that low-income, food insecure folks necessarily want to or are able to join in on garden activities, most people did not join in on the garden activities... I often felt disappointed and discouraged by the lack of volunteers who would show up at the garden. For the most part, our garden volunteer team was made up of graduate students in Sustainable Agriculture, and while I built better connections with this group of people, I often felt regret that our efforts had not attracted more members of the community... People loved the extra fresh goods at the market and at the meals. I felt valued for contributing to the growth, care, and harvest of the garden bounty despite wishing that more people would participate in such efforts.

Hannah: I began working in the garden during the second year that the garden existed. When I first began, I was excited about the mission of the garden. I assumed everybody in town would want to help out. Now I am completing my third season working in the garden and I understand how difficult it can be to engage a committed core of community volunteers. There are logistical barriers, such as the location of the garden, which can be difficult for people to access regardless of being located on a bus route, and the time of our workdays. The volunteers we have had in the garden have been great; they have learned a lot about gardening and are deeply concerned about our food system. However, the struggle to maintain high numbers of volunteers has caused the garden leaders to question our goals and capacity. Spending much of my time on campus talking and reading about the ideals of food justice and successful examples of how it is put into action, I naively assumed that people who already volunteered at and/or visited the Food at First pantry would be excited to work with us in the garden. I heard a lot of gratitude for the garden; I know our work is appreciated and that there is a need for it.

Maritza: One can argue that the garden not being an initiative by the visitors of Food at First can explain why the sense of ownership that could yield participation is missing. This garden was in some ways imposed on them by yet another group of wellintentioned people. There is... a dissonance between the intended effect of the garden and its actual effect. The garden has yet to become a community garden in the real sense of the term.

Given that our collective group inherited the garden, there was not much community discussion in terms of the location or other factors that may have influenced volunteer participation. Had we started from the beginning, we may have been better able to implement input from those benefiting from the garden, as well as potential community leaders to gain local buy-in. Moving forward, we realized the donation garden is not a sustainable model long-term, and will need to continually transform to be a true community 
resource for those benefiting from the garden, and for those that seek to have a meaningful impact in our local food system.

Carrie: Moreover, our garden has not stabilized enough to provide much needed community resources beyond food, such as skill-building or even employment (Miewald \& McCann, 2014). Building community beyond a segment of our graduate student cohort will take more than providing fresh fruits and vegetables, important though they may be.

However, we argue that the existence and contribution of the donation garden are only part of what makes our efforts towards a socially just food system. The experience has afforded us an opportunity to reflexively engage with each other, and members in our community.

Hannah: When I had conversations with Food at First guests by giving garden tours or cooking demonstrations at food distributions I learned that people faced a lot of challenges of just getting to the distribution and did not necessarily have extra time or energy to devote to a community garden.

Gabrielle: Participating in the development, maintenance and harvest of the FAF community garden helped me to pull apart the layers of our complex food system to better understand the whole. That experience provided me with the curriculum and ultimately the knowledge to more fundamentally examine the failures of our food system while celebrating the sweetness of coming together over a fresh tomato, grown in the earth, among friends.

\section{Feeding the World?}

One of the challenges our group experienced was that by working within the emergency food system we had to come to terms with the fact that hunger exists - and continues to prevail - in the heart of one of the most productive agricultural states in the world.

Gabrielle: Iowa is a net importer of food, in other words, we are a food insecure state despite the fact that the state has more land devoted to agricultural production than any other in the U.S. Story County, where Ames and Iowa State University are located, is one of the most food insecure counties in the state of Iowa. In a place that regularly champions the call for 'feeding the world,' it felt important to participate in a community garden in pursuit of growing real food for neighbors and fellow communitymembers.

Moreover, the mission to 'feed the world' is often used as a catch-all statement by Iowa State University to dominate the common discourse in Iowa and the Cornbelt. Consequently, a broader, more nuanced discussion of the agrifood system was often missing. The lack of that nuanced discussion precluded the ability to contextualize the agrifood system and its implications beyond traditional productivist worldviews, common to the U.S. Corn Belt. The GPSA program was often referred to as an alternative, nuanced 
way of thinking when it came to common discourse about the agrifood system in Iowa and within the university. Our experience with Food at First reinforced that a different paradigm is needed. Although Food at First and Trinity Reformed Christian Church are situated in the middle of the Corn Belt, characterized by the "Feed the World" narrative, they charged themselves with feeding collectively taking responsibility to make sure their neighbors own community could have basic food needs met.

Andrea: The dominance of that 'feed the world' narrative ultimately distracts from the bigger concerns of the food system, which are far more nuanced than increasing agricultural production. Reducing inequities in the food system requires talking beyond food and looking at economic issues related to trade, fair wages, sustainable working conditions, and affordable housing, to name a few.

Emily: Situated within one of the most productive agricultural regions in the world, the state of Iowa touts itself as 'feeding the world' through its industrialized, concentrated, highly efficient, and consequently, low-cost agrifood systems. Yet, as my lens expanded from a simplified biophysical approach to include socioeconomic, governance, and social justice approaches through my work with Food at First, it became increasingly clear that this food system was not even feeding Iowans.... As a biophysical scientist, much of my training prior to coming to Iowa State University to pursue my $\mathrm{PhD}$ and during my PhD centered on understanding the biophysical characteristics and relationships within our agrifood system. Consequently, the lens with which I had approached the agrifood system was often keenly focused on biophysical parameters and their relationships, such as biodiversity, hydrology, and biogeochemical cycles. My involvement with Food at First afforded me the ability to begin to understand the agrifood system outside of the biophysical lens, and encouraged me to bring critical questions of social justice into focus.

Recognizing the necessity of the emergency food system to serve the hungry, we were also deeply concerned with its reinforcement of issues underlying chronic food insecurity, which include poverty, underemployment, lack of education, and lack of insurance. We have seen firsthand and reflected on both the enormous benefit but also the limitations of relying on large, corporate donations due to concerns about nutrition, quality, desirability, and environmental impacts of donated food. As one group member reflected, the type of foods most readily available to people in need is alarming.

Andrea: The difficult aspects for me came from seeing firsthand the quality of regularly available food to those seeking food assistance, often items that are heavily processed and non-nutritionally dense. There was never a shortage of desserts, breads, or meat. Fruits and vegetables were usually available but not with the same regularity or abundance as other processed foods.

Food at First lacked quality produce because they obtained their food for distribution from unused food from local restaurants and grocery stores. They received the leftovers, not fresh local produce that can be sold for a premium. It was the lack of high quality 
produce available in our local emergency food system that empowered this group to build the donation garden.

Jackie: The lack of access to healthy food to those in need was a concern shared by our student group, which spurred efforts including starting a donation garden and gleaning from local farms to supplement the fresh food supply. We would regularly lead efforts throughout the summer to harvest, clean, and process vegetables from local farms to have fresh food for our monthly meals at the kitchen.

\section{Holistic Learning}

As graduate students interested in the food system, we found that our firsthand experiences and scholarly reflections had a large impact on our education. The experience of many students within the Graduate Program in Sustainable Agriculture (GPSA) at Iowa State University was that the curriculum fell short of connecting our agrifood system with the existence of widespread food insecurity, particularly in our own community.

Andrea: My volunteer experience with Food at First allowed me to develop a more complete picture of the food system in the state of Iowa. Sadly, that picture demonstrated for me the cognitive dissonance between what the mission of the university claims to be and what it is actually promoting in its agricultural work, meant to fulfill the popular mantra to 'feed the world'.

Maritza: Being involved with Food at First has been my principal exercise of social justice since I joined the Graduate Program in Sustainable Agriculture. Most, if not all of us, joined this program because we are eager to see changes in the way the food system operates. Having a specific interest in food security, I found the work of the Food at First organization appealing and decided to contribute.

Carrie: Then, as now, I typically explain why I garden at Food at First in terms of selfcare, community, and social justice. The only difference now is perhaps a greater degree of nuance and problematization of these theoretical categories. When I read Foucault (1995) in class and recognize that we know ourselves through our relations to power and knowledge, I map that to my experiences at Food at First. When I hear food insecurity framed as an individual decision or action, I know it is much more than that. I can theorize food security as wrapped up in a contextual web, a history of practices and knowledges that embed individual bodies, communities, and society in relations of power. Likewise, when I see the binary and oftentimes oppositional categories of social and environmental —or human and nature (or man and woman) I long for connection via an "equality in diversity," but frequently experience instead a reductionist discursive formation of environment as resource (Shiva, 1989/2002, pp. 5-6). 


\section{Praxis Guiding Learning}

As engaged scholars, we volunteered for Food at First as a way to be integrated into the local community and incorporate our interests of sustainable food systems. For many of us, Food at First was our first in-depth introduction to the emergency food system model. This model has motivated many in our group to work towards a more equitable system, a system that provides greater access to nutritious foods for food insecure members of our community.

Hannah: Learning about the challenges that contribute to food security directly from the people I sought to engage was the most powerful thing I learned during my career as a graduate student. As somebody who has a lot of privilege, understanding the need for equitable access to housing, transportation and healthcare is a powerful lesson I will take with me as I move forward with my career.

Emily: Trained as a biophysical scientist to ask "unbiased" questions, to analyze data, and to report statistical p-values, incorporating socioeconomic, governance, and social justice into my understanding of the barriers and leverage points in our agrifood system has led to a much more complex picture. The picture is much larger than I had initially envisioned, its landscape far more nuanced, and its focus warranting of several lenses-not just my biophysical lens. Importantly, Food at First not only helped me recognize the value of these different lenses, but also provided a space to talk about and experience these lenses.

Andrea: In many ways, my praxis with Food at First was the defining experience that provided for me the social justice lens which was lacking in my research on the environmental impacts of commodity crop agriculture. Unfortunately, the biophysical sciences do not often enough take into account elements of the broader social contexts from which their studies emanate: issues such as power dynamics, generation of knowledge, or social, racial and environmental justice.

Jackie: As a student in community planning and sustainable agriculture, the concepts of injustice and inequality were commonly taught in courses such as theory and sociology. While these courses were critical in my ability to understand how these concepts continue to prevail in society, my coursework ultimately fell short in teaching me how to be an agent of change. Food at First was vital for me to be able to take abstract concepts, like injustice and inequality, and place them in a local setting.

The lessons we have learned as early-career, scholar-activists working within the local emergency food system have played a tremendous part in our graduate studies, careers, and overall perspectives. Food at First provided us with a platform from which we could understand and critique the current emergency food system from the point of view of sustainability, equity and justice. The challenges of working within the emergency food system, which values quantity over quality, made it difficult to instill sustainable changes. 
Emily: Working with other members of the Graduate Program in Sustainable Agriculture and members of the Ames community who were passionate about food insecurity in our community was an opportunity to collectively and collaboratively explore ways that we could actively challenge our agrifood system through the garden.

Jackie: Even though we were using fresh produce to make meals for the patrons that we ourselves would eat, we recognized that our efforts were a stopgap solution to the larger issues around food insecurity and poverty.

Carrie: Apt critiques suggest that we produce the very conditions of injustice that we seek to overturn by propping up an emergency food system that serves as a tax deduction and waste disposal opportunity for wealthy agrifood corporations that "channel surplus food to low-income people of color" (Holt-Giménez \& Wang, 2011).

Our work to improve the types of food entering the emergency food system were wellintentioned, but were not a panacea to larger food insecurity.

\section{Conclusion}

It is important to envision what a just food system would and could look like. Envisioning such a system means understanding the root causes of food insecurity. When envisioning what a just food system looks like it is easy to ignore many of the complexities that exist in our real-world systems; however, once actions are put in place to explore the notion of a locally-just food system complexities and dualities are quick to appear. For example, we recognize that we are actively participating and reinforcing aspects of the emergency food system that most of us recognize must be fundamentally transformed. We encourage scholars and practitioners to discuss these complexities and dualities to create placed-based approaches to addressing injustices in the food system. We hope that our work with the emergency food system in our community and our reflections that have come from this work, do not serve as a model, but rather as a starting point in a conversation on how different actors in our food system can work together to build food justice.

Realizing social justice is a slow and difficult process because systems of oppression are normalized and interwoven into our social fabric, our social institutions, and our everyday relations. Undoing histories of marginalization and redefining who benefits in the food system is slow and laborious work that involves long-term commitments to relationship building and political action. However, not engaging in the work because it takes too long or is too hard is simply not an option. Over the past four growing seasons we have learned about growing food, complex dynamics associated with the emergency food system and the larger agrifood system that our work is situated within. As students, we continue to cycle through GPSA, but our hope is that the garden and our partnerships with Trinity Reformed Christian Church and Food at First continue. We hope that current and future students and other practitioners in other communities might work together to manage and grow community donation gardens in ways that are fundamentally connected to the goals of food justice. As students graduate and move away we continue to build relationships in our communities, especially with marginalized community members, regardless of whether we have moved on to other communities post-graduation. Through 
building trusting relationships and alliances, it may enable our communities of practice to make broader impacts and transformations towards more justice food systems.

\section{Acknowledgements}

We are grateful for the support from the Graduate Program in Sustainable Agriculture, Food at First and Trinity Reformed Christian Church. The garden would not be possible without this partnership.

\section{Author Notes}

Hannah Dankbar is a Coastal Planner with CREST (Columbia River Estuary Study Taskforce) based out of Astoria, Oregon where she helps communities with land use and environmental planning projects. She also spends time researching how communities can foster sustainable food systems, food justice movements, and sustainable agricultural practices.

Emily Zimmerman is a $\mathrm{PhD}$ candidate at Iowa State University, majoring in Sustainable Agriculture and Environmental Science. Her research focuses on identifying and evaluating social-ecological opportunities for the production of a diverse suite of ecosystem services in working landscapes.

Carrie Chennault is a $\mathrm{PhD}$ candidate at Iowa State University, majoring in Sustainable Agriculture and minoring in Women's and Gender Studies. Ms. Chennault's research focuses on food insecurity and local food systems in Iowa. She collaborates with community donation gardeners across the state and explores how growing and donating nutritious food, while vitally important, depends on forming more socially just and caring relationships through which the food is grown, distributed, and consumed.

Andrea Basche is a Kendall Science Fellow with the Food and Environment Program at the Union of Concerned Scientists, Washington, D.C. Her research explores the opportunities for climate risk reduction through agroecology, and her broader interests include science communication, science policy and advancing more equitable food system outcomes.

Jackie Nester is a Planner for Monroe County, Indiana. Her work guides responsible residential and commercial development, and helps to educate the public on environmental restrictions in the county. She also spends time researching new ordinance language for urban agriculture, agritourism, and rural business activities to preserve rural character and food system sustainability.

Maritza Pierre is working on a double Master degree in Sustainable Agriculture and Community and Regional Planning at Iowa State University. Her interests include food sovereignty, food waste reduction, sustainable planning, and agroforestry. 
Gabrielle Roesch-McNally is a Fellow with the USDA Northwest Climate Hub. Her research interests include: adaptive and mitigative decision making on managed landscapes, constrained choice, coproduction of scientific knowledge, soil health and stewardship, and social-ecological system linkages.

\section{References}

Alkon, A. H. (2014). Food justice and the challenge to neoliberalism. Gastronomica: The Journal of Critical Food Studies,14(2), 27-40. http://dx.doi.org/10.1525/gfc.2014.14.2.27

APA Policy Guide on Planning for Sustainability (2000). In American Planning Association. Retrieved September 16, 2016.

Araghi, F. (1995). Global depeasantization, 1945-1990. The Sociological Quarterly, 36(2), 337368. Retrieved from http://www.jstor.org/stable/4120791

Arnstein, S. (1969). A Ladder Of Citizen Participation. Journal of the American Institute of Planners, 35(4), 216-224. http://dx.doi.org/10.1080/01944366908977225

FAO. (2003). Trade reforms and food security: conceptualising the linkages. Retrieved from http://www.fao.org/docrep/005/y4671e/y4671e00.htm.

Fairbairn, M. (2012). Framing transformation: the counter-hegemonic potential of food sovereignty in the US context. Agriculture and Human Values, 29(2), 217-230. http://dx.doi.org/10.1007/s10460-0119334-x

Feeding America. (2014). Map the food gap: Food insecurity in Story County. Retrieved from http://map.feedingamerica.org/county/2014/overall/iowa/county/story

Foucault, M. (1995). Discipline and punish. New York, NY: Vintage Books.

Gibson-Graham, J. K., Cameron, J., Healy, S. (2013). Take back the economy: An ethical guide for transforming our communities. Minneapolis, MN: University of Minnesota Press.

Goetz, SJ and H. Swaminathan, "Walmart and county wide poverty." Social Science Quarterly, 87, no. 2 (2006):211.

Guthman, J. (2008). Bringing good food to others: Investigating the subjects of alternative food practice. Cultural Geographies, 15(4), 431-447. http://dx.doi.org/10.1177/1474474008094315

Hale, Charles R. (2008). Engaging Contradictions: Theory, Politics, and Methods of Activist Scholarship Location: Global, Area, and International Archive. GAIA Books, 6. Retrieved from: http://escholarship.org/uc/item/7z63n6xr

Hayes CR, Carbone ET (2015) Food Justice: What is it? Where has it been? Where is it going? J Nutr Disorders Ther 5:179. doi:10.4172/2161-0509.1000179

Healey, P. (2012). Traditions of Planning Thought. In S. Fainstein \& S. Campbell (Eds.), Readings in Planning Theory (3rd ed., pp. 214-233). West Sussex: Wiley-Blackwell.

Holt-Giménez, E., \& Wang, Y. (2011). Reform or transformation? The pivotal role of food justice in the U.S. food movement. Race/Ethnicity: Multidisciplinary Global Contexts, 5(1), 83-102. http://dx.doi.org/10.2979/racethmulglocon.5.1.83

Jarosz, L. (2014). Comparing food security and food sovereignty discourses. Dialogues in Human Geography, 4(2), 168-181. http://dx.doi.org/10.1177/2043820614537161

Katz, C. (1992). All the world is staged: Intellectuals and the project of ethnography. Environment and Planning: Society and Space, 10(5), 495-510. http://dx.doi.org/10.1068/d100495http://dx.doi.org/10.1068/d100495

Miewald, C., \& McCann, E. (2014). Foodscapes and the geographies of poverty: Sustenance, strategy, and politics in an urban neighborhood. Antipode, 46(2), 537-556. http://dx.doi.org/10.1111/anti.12057

Minkoff-Zern, L. A. (2014). Knowing "good food": Immigrant knowledge and the racial politics of farmworker food insecurity. Antipode, 46(5), 1190-1204. http://dx.doi.org/10.1111/j.14678330.2012.01016.x

Mohanty, C. (1984). Under Western eyes: Feminist scholarship and colonial discourses. Boundary 2, 12/13, 333-358. http://dx.doi.org/10.2307/302821 
Nestle, M. (2014). Foreward. In J. Poppendieck, Breadlines knee-deep in wheat: Food assistance in the Great Depression (pp. ix-xii). Berkeley, CA: University of California Press.

Patel, R. (2009). Food Sovereignty. The Journal of Peasant Studies, 36(3), 663-706.

Poppendieck, J. (2014). Breadlines knee-deep in wheat: Food assistance in the Great Depression. Berkeley, CA: University of California Press.

Roesch-McNally, G., Nester, J., Basche, A., Christianson, E., \& Zimmerman, E. (forthcoming 2017). Hunger in the land of plenty: Local responses to food insecurity in Iowa. In Hossfeld, L., Kelly, E.B., and J. Waity (eds), Food and poverty: Food insecurity and food sovereignty among America's poor.

Schiavoni, C. (2009). The global struggle for food sovereignty: From Nyéléni to New York. The Journal of Peasant Studies, 36(3), 682-689.

Shiva, V. (1989/2002). Staying alive: Women, ecology, and development. London, UK: Zed Books.

Slocum, R., \& Saldanha, A. (2016). Geographies of race and food: Fields, bodies, markets. London, UK: Routledge.

Windfuhr, M. \& J. Jonsen. (2005). Food Sovereignty: Toward democracy in localized food systems. Retrieved from http://www.ukabc.org/foodsovereignty_itdg_fian_print.pdf 